Proc. Estonian Acad. Sci. Geol., 2005, 54, 2, 87-111

\title{
Chitinozoans of the Margachitina margaritana Biozone and the Llandovery-Wenlock boundary in West Estonian drill cores
}

\begin{abstract}
Viiu Nestor
Institute of Geology at Tallinn University of Technology, Estonia pst. 7, 10143 Tallinn, Estonia; vnestor@gi.ee

Received 9 November 2004, in revised form 7 January 2005

Abstract. The succession of chitinozoan taxa in the uppermost Llandovery and lowermost Wenlock of the Viki, Ohesaare, Kaugatuma, and Ruhnu drill core sections is described and correlated with the global stratotype section of the basal Wenlock in Hughley Brook, Shropshire, England. The most important biomarkers for the identification of the Llandovery-Wenlock boundary in Estonian sections are the disappearance levels of Ramochitina nestorae, Conochitina acuminata, C. cf. flamma, and Angochitina longicollis. In the West Estonian cores this boundary corresponds to a level in the middle or upper part of the Margachitina margaritana Biozone. In the Viki and Ohesaare cores it coincides with the bentonite layers above the accepted boundary between the Adavere and Jaani regional stages and correlates with a level in the middle of the murchisoni graptolite Biozone. Three new species, Belonechitina oeselensis, Ancyrochitina mullinsi, and Eisenackitina inanulifera, are described.
\end{abstract}

Key words: chitinozoans, correlation, Llandovery, Wenlock, Silurian, Estonia.

\section{INTRODUCTION}

The boundary between the Adavere and Jaani regional stages in Estonian sections has been considered as the Llandovery-Wenlock boundary (Kaljo 1962). In the Ohesaare drill core a metabentonite layer at a depth of $345.8 \mathrm{~m}$ has been treated as the boundary marker of the stratotype level between the Adavere and Jaani stages (Nestor 1997). According to Kaljo (1962) and Loydell et al. (1998), 
a fragment of Cyrtograptus is present at $345.11-345.14 \mathrm{~m}$, being indicative of the lowermost Wenlock. The interval of 352.80-345.14 m did not yield zonal graptolites. In the Ohesaare core, as in some other sections, a change in sediment colour can be traced at the boundary level. The greenish mudstones of the uppermost Llandovery (Velise Formation) are replaced by dark grey or brownish mudstones in the basal Wenlock (Riga Formation). The study of the Aizpute-41 core showed that the change in colour does not always correspond to the position of the Llandovery-Wenlock boundary (Loydell et al. 2003, figs. 2, 12). In more calcareous sections this boundary is usually lithologically indistinct. In addition, a stratigraphical gap was proven to exist at the junction of the Adavere and Jaani stages, having a considerable areal extent and stratigraphical range in southwestern Estonia and northernmost Latvia (Nestor \& Nestor 2002). This also complicates the exact definition of the boundary.

The international stratotype for the base of the Wenlock Series has been defined in the Hughley Brook section in Shropshire, Welsh Borderland (Bassett et al. 1975). It is a transition between purple and grey-green mudstones, where no graptolites have been recorded and correlation with the graptolite biozonation is based on indirect evidences from other sections. The use of microfossils for correlation of the base of the Wenlock was investigated by Mabillard \& Aldridge (1985), but they estimated that the base did not coincide with the base of any microfossil biozone. A re-examination of microfossils, particularly chitinozoans from the samples of the Hughley Brook section was recently undertaken by Mullins \& Aldridge (2004). They describe a diverse and abundant assemblage of chitinozoans, containing also new species and forms. This study stimulated re-examination of chitinozoans from the Llandovery-Wenlock boundary interval in some Estonian drill cores with the aim of finding possibilities of more precise correlation with the international boundary stratotype in Welsh Borderland.

In the chitinozoan zonal succession the base of the Margachitina margaritana Biozone has gained special attention as a possible criterion for the determination of the Llandovery-Wenlock boundary. At first it was recorded just above the Wenlock boundary in the Ohesaare core (Nestor 1984), then also at the base of the Wenlock in the international boundary stratotype (Mabillard \& Aldridge 1985). Later it has been used as a marker of the Llandovery-Wenlock boundary in a global biozonal scheme of chitinozoans (Verniers et al. 1995). Recent investigation of chitinozoans and graptolites in the Welsh area (Mullins 2000; Mullins \& Loydell 2001) enables a detailed correlation between the graptolite and chitinozoan biozones, including the determination of a more exact position for the base of the M. margachitina Biozone. It appears to lie within the lowermost insectus Biozone in the graptolite zonal succession (Mullins \& Loydell 2001), being indicative of the uppermost Llandovery. 


\section{CHITINOZOAN BIOSTRATIGRAPHY}

Thirty-one biozonal units were established in the entire Silurian sequence of the East Baltic (Nestor 1990), five of which were treated as interzones, poorly characterized by chitinozoans. Later Nestor (1994) described more precisely 22 biozones from the Llandovery and Wenlock.

In this paper the chitinozoan succession in the upper Telychian and lower Wenlock beds of some West Estonian core sections (Fig. 1) is discussed. The ranges of chitinozoan species in the Viki (Fig. 2), Kaugatuma (Fig. 3), Ohesaare (Fig. 4), and Ruhnu (Fig. 5) cores are illustrated. The most characteristic biozone succession in ascending order is the following: Angochitina longicollis, Conochitina proboscifera, C. acuminata, and Margachitina margaritana. In the Ohesaare core also the Margachitina banwyensis Biozone is established. In some cases the zonal species may appear almost simultaneously or close to each other, for instance C. acuminata, M. banwyensis, and M. margaritana in

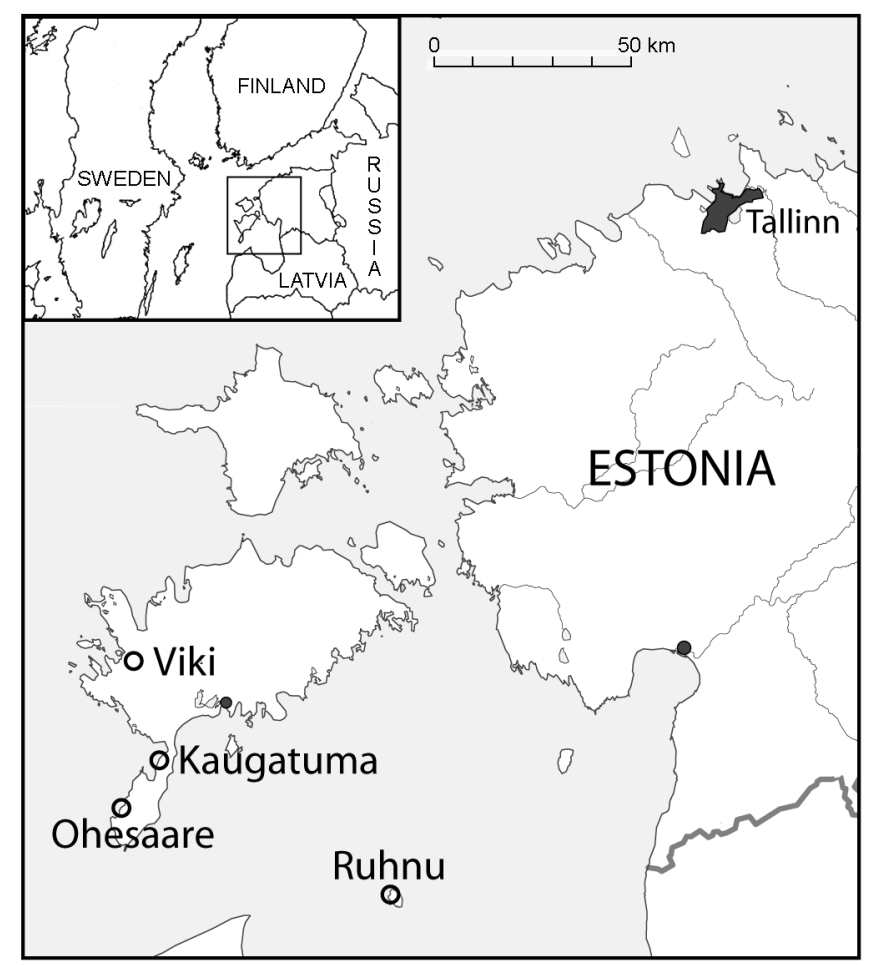

Fig. 1. Location of the studied West Estonian drill holes. 
Viki core

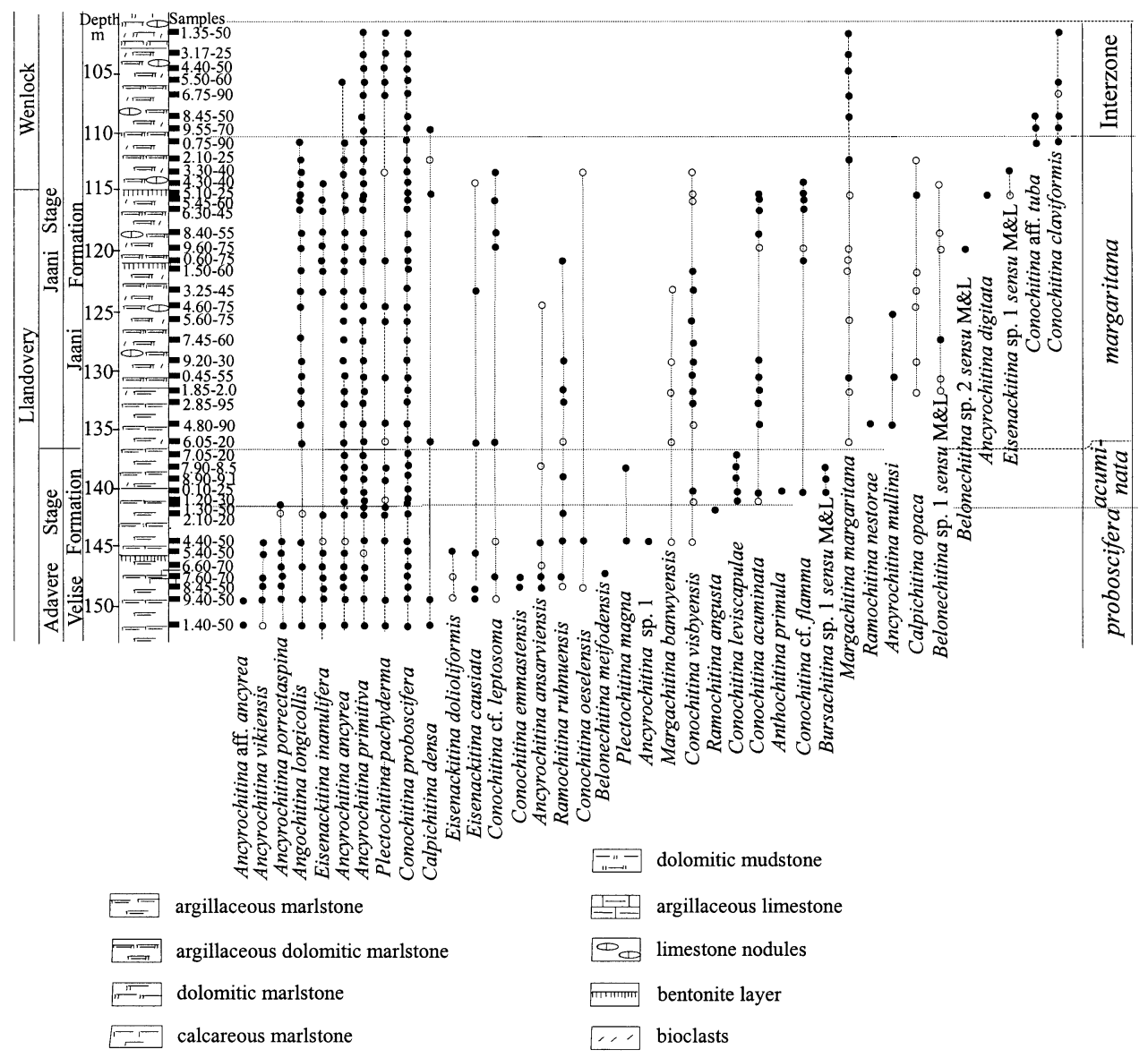

Fig. 2. Lithological log and ranges of chitinozoan species in the Llandovery-Wenlock boundary interval in the Viki drill core.

the Kaugatuma core (Fig. 3), Margachitina banwyensis and M. margaritana in the Ruhnu core (Fig. 5) or C.proboscifera and M. margaritana in the Ventspils core (Loydell \& Nestor in press), which complicates the identification of several biozones.

Figures 2-5 display only the upper part of the C. proboscifera Biozone. The C. acuminata Biozone is distinguished in the Ohesaare, Viki, and Ruhnu cores, the Margachitina banwyensis Biozone only in the Ohesaare core. The upper boundary of the M. margaritana Biozone is marked in the East Baltic sections by 
the disappearance of $A$. longicollis; above that level an Interzone is present, ranging up to the appearance of Conochitina mamilla, the index species of the covering biozone (see Nestor 1994).

Kaugatuma core

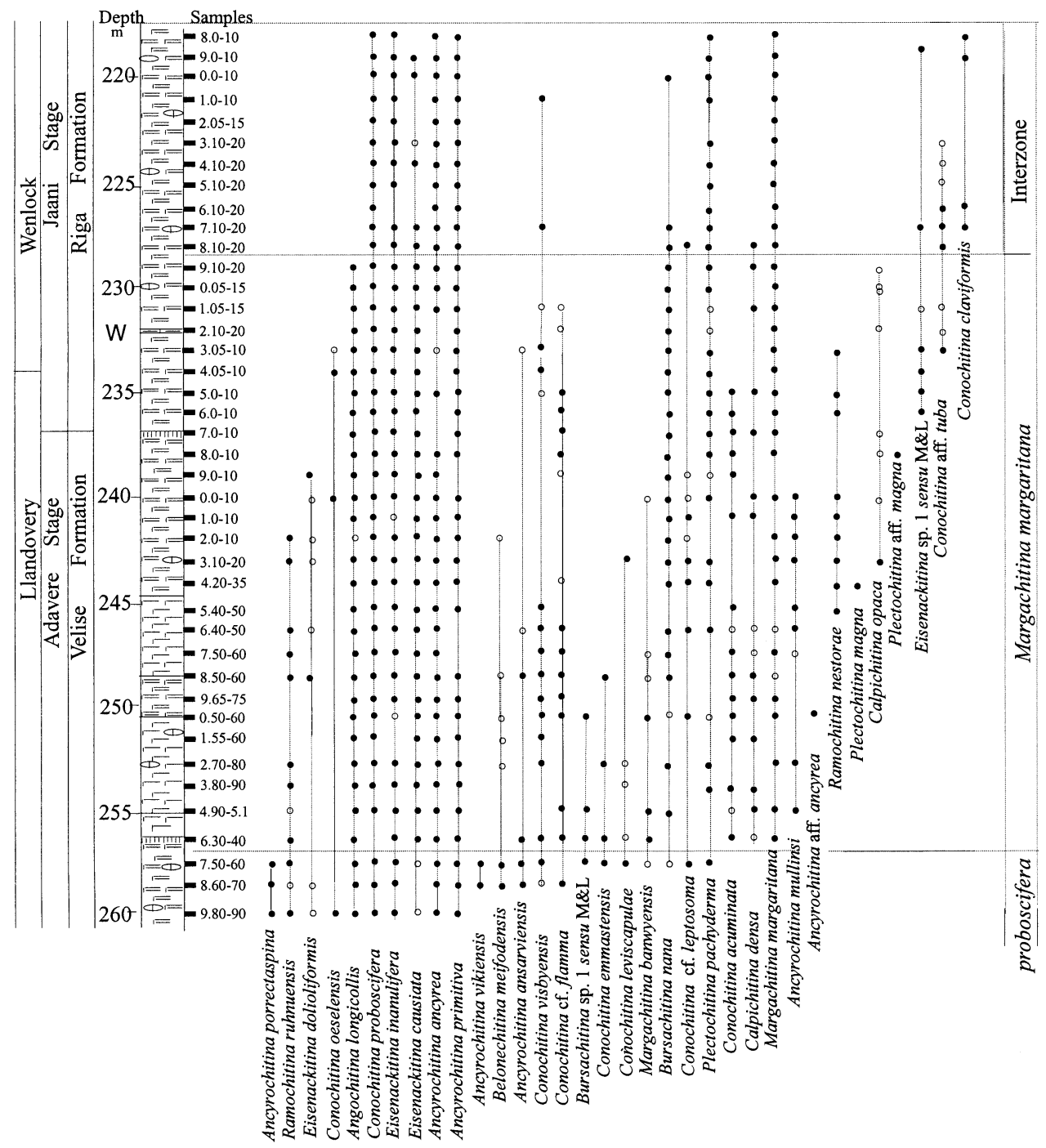

Fig. 3. Lithological log and ranges of chitinozoan species in the Llandovery-Wenlock boundary interval in the Kaugatuma drill core. For legend see Fig. 2. 
Ohesaare core

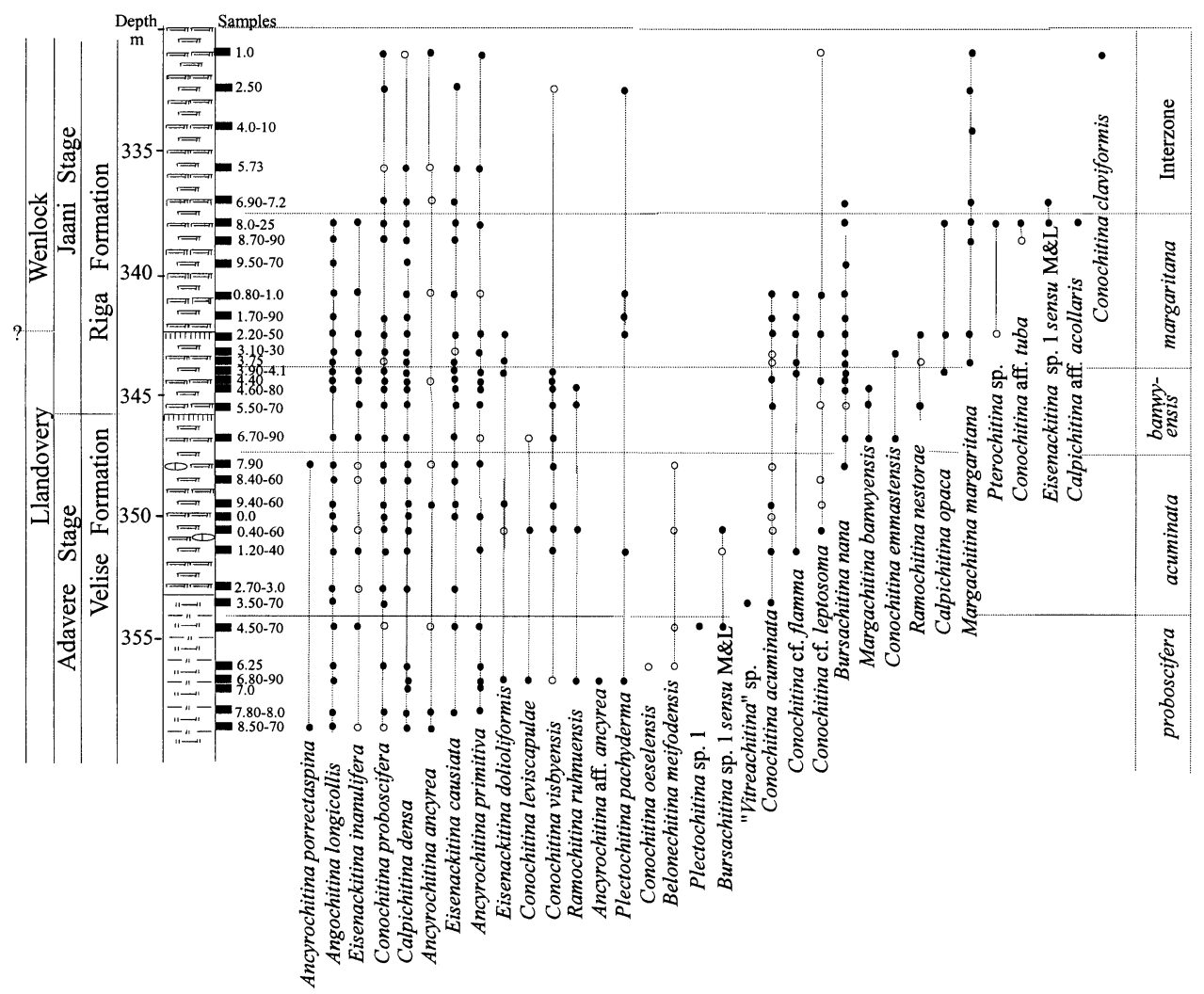

Fig. 4. Lithological log and ranges of chitinozoan species in the Llandovery-Wenlock boundary interval in the Ohesaare drill core. For legend see Fig. 2.

\section{Chitinozoan distribution below the Margachitina margaritana Biozone}

Most of the chitinozoan taxa occurring in the C.proboscifera and C.acuminata biozones range from the lower or middle Telychian. The appearance level of some species has been connected with graptolite data. Angochitina longicollis Eisenack (Pl. I, fig. 7) is represented from the lower part of the spiralis graptolite Biozone (Loydell et al. 2003; Põldvere et al. 2003), C. proboscifera Eisenack (P1. I, figs. 8, 9) from the middle or upper spiralis Biozone (Loydell et al. 2003; Loydell $\&$ Nestor in press). The appearance of Ramochitina ruhnuensis (Nestor) (P1. I, fig. 3) is probably related to the lowermost lapworthi Biozone (Loydell et al. 1998). According to Mullins \& Loydell (2001), the Conochitina acuminata Biozone is 
Ruhnu core

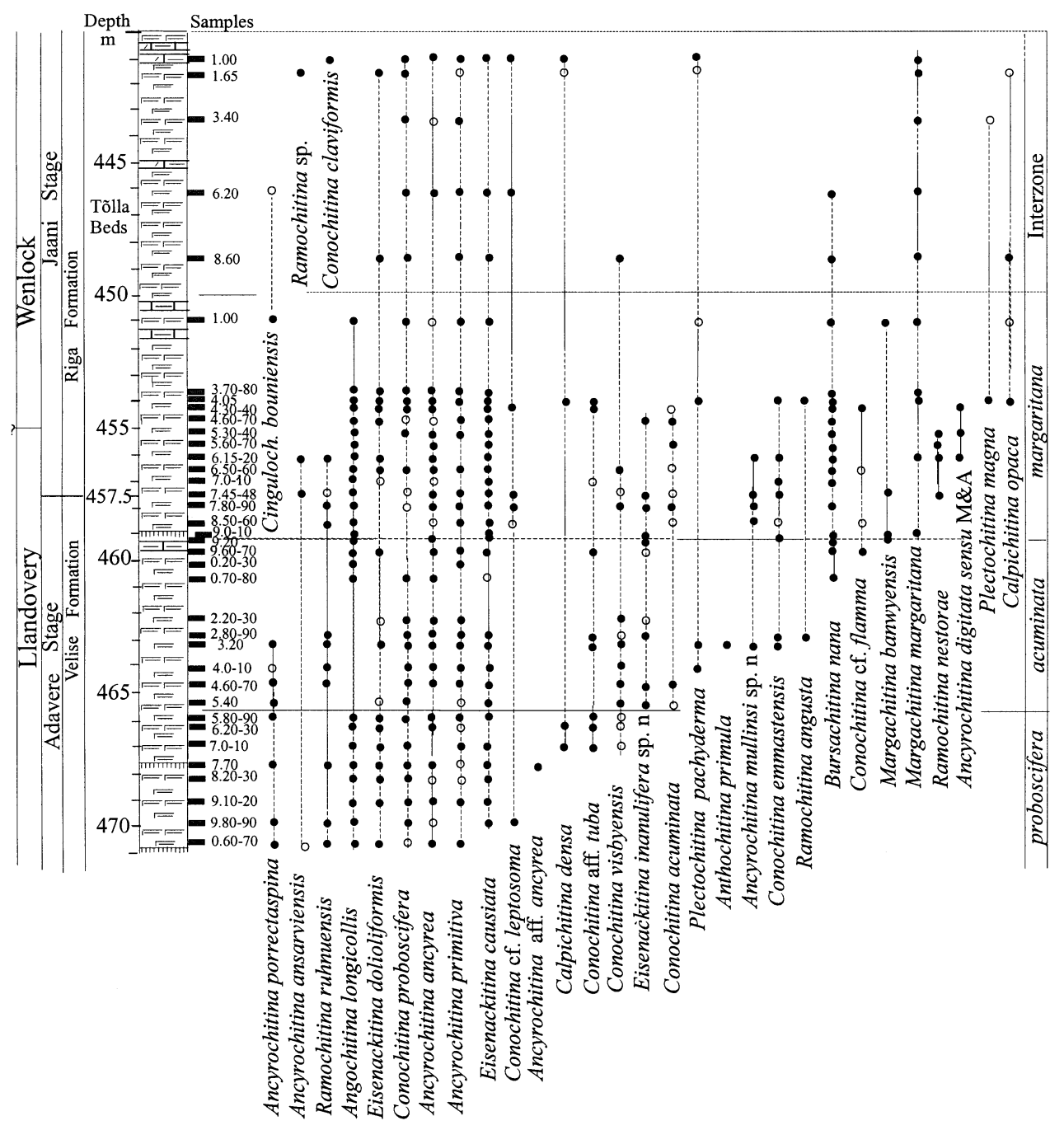

Fig. 5. Lithological log and ranges of chitinozoan species in the Llandovery-Wenlock boundary interval in the Ruhnu drill core. For legend see Fig. 2.

correlated with the lapworthi Biozone in the Banwy River section. In the Ohesaare core the lapworthi Biozone has been established at 356.14 and $352.80-352.88 \mathrm{~m}$ (Loydell et al. 1998). The latter interval corresponds to the lower part of the C. acuminata Biozone (Fig. 4). Besides C. acuminata Eisenack (Pl. II, fig. 9), there occur more frequently C. proboscifera and C. visbyensis Laufeld (Pl. I, fig. 16). 
PLATE I

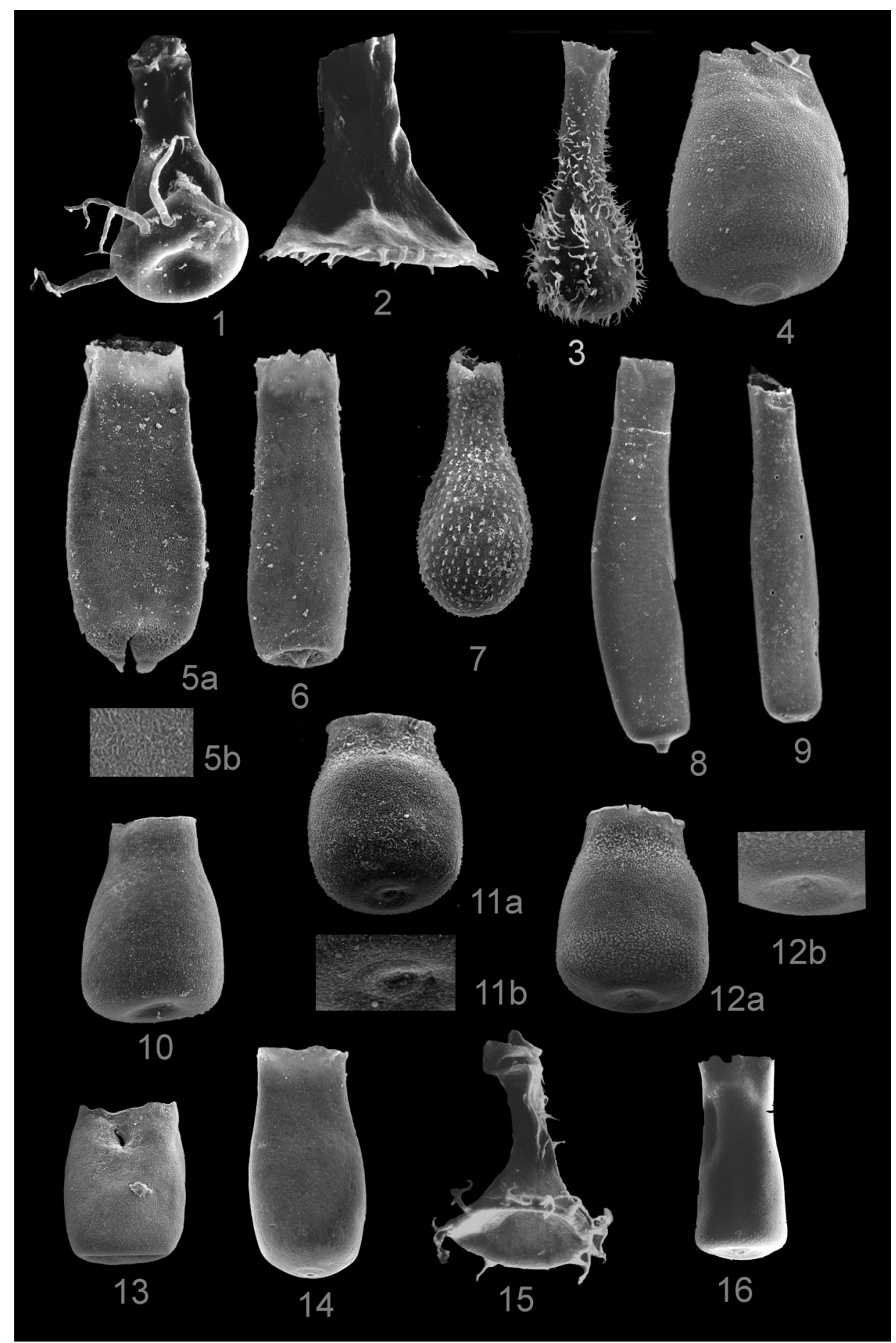


In the upper part of this zone Conochitina cf. flamma Laufeld (Pl. II, fig. 1) and Bursachitina nana (Nestor) make their appearance (Pl. II, figs. 4-6). Quite unique are the findings of Anthochitina primula Nestor (Pl. III, fig. 6) in the C. acuminata Biozone of the Viki and Ruhnu cores. Below the M. margaritana Biozone, Ancyrochitina porrectaspina Nestor (Pl. I, fig. 1) disappears, as do A. vikiensis Nestor (Pl. I, fig. 15), Belonechitina cf. meifodensis Mullins \& Loydell (Pl. I, fig. 14) and Bursachitina sp. 1 by Mullins \& Loydell (2001).

Margachitina banwyensis Mullins (Pl. II, fig. 11) has been described from the Wenlock type area (Mullins 2000) as a predecessor of M. margaritana. In the

\section{Explanation of Plate I}

Fig. 1. Ancyrochitina porrectaspina Nestor 1994, GIT 272-39, Ruhnu core, depth 464.60-464.70 m, Adavere Stage, $\times 250$.

Fig. 2. Ancyrochitina ansarviensis Laufeld 1974, GIT 272-27, Viki core, depth 148.45-148.50 m, Adavere Stage, $\times 440$.

Fig. 3. Ramochitina ruhnuensis (Nestor 1982), GIT 427-1, Kaugatuma core, depth 242.0-242.10 m, Adavere Stage, $\times 200$.

Fig. 4. Eisenackitina dolioliformis Umnova 1976, GIT 427-2, Kaugatuma core, depth 246.45-246.55 m, Adavere Stage, $\times 180$.

Figs. 5, 6. Belonechitina oeselensis sp. nov., Adavere Stage. 5, Holotype GIT 427-3, Kaugatuma core, depth $234.05-235.10 \mathrm{~m}: 5 \mathrm{a}, \times 180$; 5b, close-up of the ornament, $\times 400$. 6, GIT 427-4, Kaugatuma core, depth $240.0-240.10 \mathrm{~m}, \times 145$.

Fig. 7. Angochitina longicollis Eisenack 1959, GIT 427-5, Kaugatuma core, depth 235.0-235.10 m, Adavere Stage, $\times 185$.

Figs. 8, 9. Conochitina proboscifera Eisenack 1937, Kaugatuma core, depth 245.40-245.50 m, Adavere Stage, $\times 140.8$, GIT 427-6; 9, GIT 427-7.

Figs. 10-12. Eisenackitina inanulifera sp. nov., Kaugatuma core, Adavere Stage. 10, GIT 427-8, depth $235.0-235.10 \mathrm{~m}, \times 160$. 11, Holotype GIT 427-9, depth $242.0-242.10 \mathrm{~m}$ : $11 \mathrm{a}, \times 160$; $11 \mathrm{~b}$, close-up of the mucron, $\times 700$. 12, GIT 427-10, depth $242.0-242.10 \mathrm{~m}: 12 \mathrm{a}, \times 160 ; 12 \mathrm{~b}$, closeup of the mucron, $\times 700$.

Fig. 13. Eisenackitina causiata Verniers 1999, GIT 427-11, Kaugatuma core, depth 237.0-237.10 m, Adavere Stage, $\times 160$.

Fig. 14. Belonechitina cf. meifodensis Mullins \& Loydell 2001, GIT 427-12, Kaugatuma core, depth 242.0-242.10 m, Adavere Stage, $\times 150$.

Fig. 15. Ancyrochitina vikiensis Nestor 1994, GIT 272-27, Viki core, depth 147.45-147.60 m, Adavere Stage, $\times 300$.

Fig. 16. Conochitina visbyensis Laufeld 1974, GIT 272-135, Ohesaare core, depth 349.40-349.60 m, Adavere Stage, $\times 230$. 
PLATE II

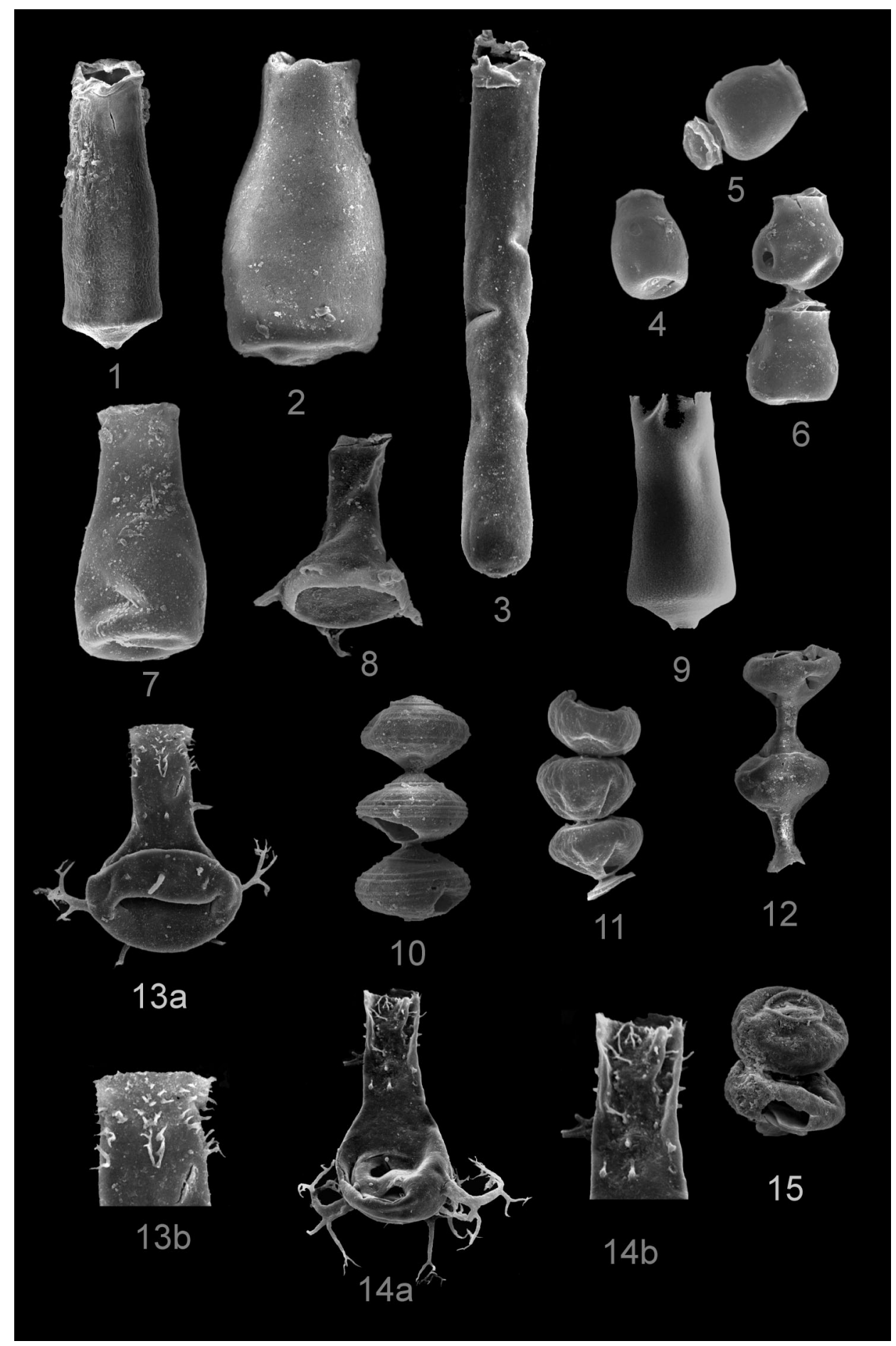


East Baltic sections the M. banwyensis Biozone is usually hardly distinguishable from the M. margaritana Biozone as the index species occurs sporadically and appears usually very close $(0.2-1.0 \mathrm{~m})$ to the base of the M. margaritana $(\mathrm{Pl}$. II, fig. 12) Zone. In the Ohesaare core this biozone is identified in the interval of about 343.80-347.40 m, embracing at least the lowest part of the murchisoni graptolite Biozone (Loydell et al. 1998). In the Banwy River section the M. banwyensis Biozone correlates with the upper part of the lapworthi and lower part of the insectus graptolite biozones, but the zonal species ranges up to the topmost centrifugus Biozone (Mullins \& Loydell 2001).

\section{Explanation of Plate II}

Fig. 1. Conochitina flamma Laufeld 1974, GIT 427-13, Kaugatuma core, depth 237.0-237.10 m, Adavere Stage, $\times 170$.

Fig. 2. Conochitina emmastensis Nestor 1982, GIT 427-14, Kaugatuma core, depth 252.70-252.80 m, Adavere Stage, $\times 115$.

Fig. 3. Conochitina cf. leptosoma Laufeld 1974, GIT 427-15, Kaugatuma core, depth 241.0-241.10 m, Adavere Stage, $\times 120$.

Figs. 4-6. Bursachitina nana (Nestor 1994), Kaugatuma core, Adavere Stage. 4, 5, depth 237.0$237.10 \mathrm{~m}, \times 130.4$, GIT 427-16; 5, GIT 427-17. 6, GIT 427-17, depth 240.0-240.10 m, $\times 120$.

Fig. 7. Conochitina cf. leviscapulae Mullins \& Loydell 2001, GIT 427-18, Kaugatuma core, depth 243.10-243.20 m, Adavere Stage, $\times 120$.

Fig. 8. Plectochitina pachyderma (Laufeld 1974), GIT 427-19, Kaugatuma core, depth 236.0-236.10 m, Adavere Stage, $\times 235$.

Fig. 9. Conochitina acuminata Eisenack 1959, GIT 272-62, Ohesaare core, depth $349.40 \mathrm{~m}$, Adavere Stage, $\times 290$.

Fig. 10. Calpichitina densa (Eisenack 1962), GIT 427-20, Kaugatuma core, depth 250.50-250.60 m, Adavere Stage, $\times 140$.

Fig. 11. Margachitina banwyensis Mullins 2000, GIT 427-21, Kaugatuma core, depth 240.0-240.10 m, Adavere Stage, $\times 140$.

Fig. 12. Margachitina margaritana (Eisenack 1937), GIT 427-22, Kaugatuma core, depth 240.0 $240.10 \mathrm{~m}$, Adavere Stage, $\times 140$.

Figs. 13, 14. Ancyrochitina mullinsi sp. nov., Kaugatuma core, Adavere Stage. 13, Holotype GIT 427-23, depth $242.0-242.10 \mathrm{~m}: 13 \mathrm{a}, \times 220$; 13b, close-up of the neck ornament, $\times 400.14$, GIT 427-24, depth $246.40-246.50 \mathrm{~m}: 14 \mathrm{a}, \times 200 ; 14 \mathrm{~b}$, close-up of the neck ornament, $\times 330$.

Fig. 15. Calpichitina opaca (Laufeld 1974), GIT 427-25, Ohesaare core, depth 342.20 m, Adavere Stage, $\times 140$ 
PLATE III

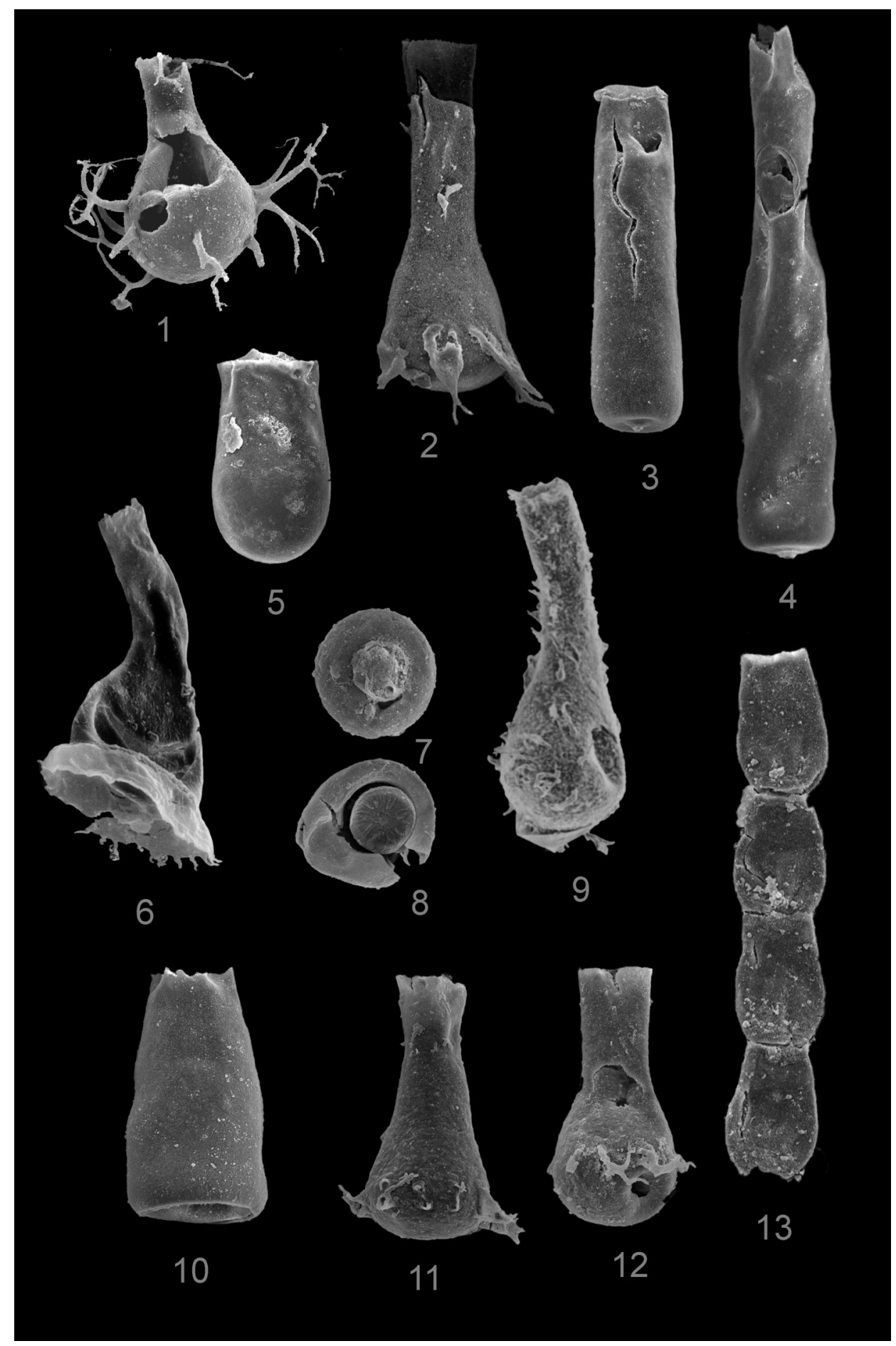




\section{The Margachitina margaritana Biozone}

In the East Baltic core sections this biozone is defined from the appearance level of the zonal species up to the disappearance of Angochitina longicollis (Nestor 1990, 1994). The thickness of this biozone is quite different in the studied cores: it is thicker in the Kaugatuma $(28.3 \mathrm{~m})$ and Viki $(27.2 \mathrm{~m})$ cores, but thinner in the Ohesaare $(6.15 \mathrm{~m})$ and Ruhnu $(9.0 \mathrm{~m})$ cores. The most diverse assemblage of chitinozoans (30 species) occurs in the Kaugatuma core. Twenty-six species have been distinguished in the Ruhnu and Viki cores and 21 species in the Ohesaare core. In this biozone some levels of chitinozoan extinction as the "datums" of the Ireviken Event were recognized. The disappearance of $C$. acuminata and

\section{Explanation of Plate III}

Fig. 1. Ramochitina nestorae Grahn 1995, GIT 427-26, Kaugatuma core, depth 243.10-243.20 m, Adavere Stage, $\times 175$.

Fig. 2. Plectochitina magna (Nestor), GIT 427-27, Kaugatuma core, depth 244.20-244.35 m, Adavere Stage, $\times 110$.

Fig. 3. Conochitina aff. tuba Eisenack 1932, GIT 427-28, Kaugatuma core, depth 233.05-233.15 m, Jaani Stage, $\times 110$.

Fig. 4. Conochitina claviformis Eisenack 1931, GIT 427-29, Viki core, depth 110.75-110.90 m, Jaani Stage, $\times 110$.

Fig. 5. Eisenackitina sp. 1 sensu Mullins \& Loydell 2001, GIT 427-30, Kaugatuma core, depth 231.05-231.15 m, Jaani Stage, $\times 190$.

Fig. 6. Anthochitina primula Nestor 1994, GIT 272-31, Viki core, depth 140.10-140.25 m, Adavere Stage, $\times 240$

Figs. 7, 8. Calpichitina aff. acollaris (Eisenack 1959), GIT 427-31, Ohesaare core, depth 338.25$338.30 \mathrm{~m}$, Jaani Stage, $\times 290$.

Fig. 9. Ramochitina angusta (Nestor 1982), GIT 219-3, Ruhnu core, depth 454.05 m, Jaani Stage, $\times 180$.

Fig. 10. Belonechitina sp. 2 sensu Mullins \& Loydell 2001, GIT 427-32, Viki core, depth 119.60 $119.75 \mathrm{~m}$, Adavere Stage, $\times 170$.

Figs. 11, 12. Ancyrochitina digitata Mullins \& Aldridge 2004, Ruhnu core, depth $454.05 \mathrm{~m}$, Jaani Stage. 11 , GIT $427-33, \times 200.12$, GIT $427-34, \times 170$.

Fig. 13. Cingulochitina bouniensis Verniers 1999, chain of four vesicles GIT 427-35, Ruhnu core, depth 451.0 m, Jaani Stage, $\times 140$. 
C. cf. flamma characterizes the second event level, correlating with a level between conodont datums 2 and 3 (see Nestor et al. 2002). The most important level (8) in the chitinozoan succession is the disappearance of $A$. longicollis, corresponding to the conodont datum 6.2 in the Ireviken 3 section (Jeppsson \& Männik 1993; Nestor et al. 2002). In addition to M. margaritana, in this biozone there appear Ramochitina nestorae Grahn (Pl. III, fig. 1), Ancyrochitina mullinsi sp. nov. (Pl. II, figs. 13, 14), Plectochitina magna (Nestor) (P1. III, fig. 2), Calpichitina opaca (Laufeld) (Pl. II, fig. 15), Ancyrochitina digitata Mullins \& Aldridge (Pl. III, figs. 11, 12), Belonechitina sp. 2 sensu Mullins \& Loydell (Pl. III, fig. 10). The uppermost part of the biozone is characterized by the appearance of Eisenackitina sp. 1 sensu Mullins \& Loydell (Pl. III, fig. 5) and Conochitina aff. tuba Eisenack (P1. III, fig. 3) in most of the studied sections, but also tiny Calpichitina aff. acollaris (Eisenack) (Pl. III, figs. 7, 8) are found in the Ohesaare core and Cingulochitina bouniensis Verniers (Pl. III, fig. 13) in the Ruhnu core. Most of the species, occurring more or less numerously in the lower and middle Telychian, disappeared in the M. margaritana Biozone and following Interzone, among them Eisenackitina dolioliformis Umnova (Pl. I, fig. 4), E. causiata Verniers (P1. I, fig. 13), E. inanulifera sp. nov. (Pl. I, figs. 10-12), Calpichitina densa (Eisenack) (Pl. II, fig. 10), Ancyrochitina ansarviensis Laufeld (Pl. I, fig. 2), Conochitina emmastensis Nestor (Pl. II, fig. 2), C. oeselensis sp. nov. (Pl. I, figs. 5, 6), C. cf. leviscapulae Mullins \& Loydell (Pl. II, fig. 7), and also C. proboscifera, the dominant species for the uppermost Llandovery and lowermost Wenlock strata. Only a few species, such as Plectochitina pachyderma (Laufeld) (Pl. II, fig. 8), Conochitina cf. leptosoma Laufeld (Pl. II, fig. 3), Ancyrochitina ancyrea (Eisenack), and $A$. primitiva Eisenack, continue their range upwards. The index species of the succeeding biozone, C. claviformis Eisenack (P1. III, fig. 4), appears within or just above the Interzone. It is worth mentioning that the Interzone corresponds to the firmus and riccartonensis graptolite biozones (Loydell et al. 2003).

\section{The Llandovery-Wenlock transition}

Chitinozoans from 20 samples of the boundary stratotype section of Hughley Brook were recently re-examined by Mullins \& Aldridge (2004). Thirty-three species (including different formas) were distinguished (Fig. 6), 16 of which are also identified in the boundary beds of West Estonian core sections. All four formas of C. proboscifera, distinguished by Mullins and Aldridge, are present also in the studied Estonian cores, but their occurrence seems to be irregular. The ranges of stratigraphically most important species at the Llandovery-Wenlock transition are shown in Fig. 7. The topmost part of the range of C. acuminata is also included in Fig. 7, as the disappearance level of this species as well as 
C. cf. flamma may indicate the approximate position of the Llandovery-Wenlock boundary, determined by conodonts as Datum 2 in the Ireviken 3 locality (Jeppsson \& Männik 1993; Nestor et al. 2002). The interval covered by the studied samples is about $0.1 \mathrm{~m}$ in the Hughley Brook section, but about $1 \mathrm{~m}$ in the Estonian cores. The thickness of the displayed part of the Hughley Brook section is $1.28 \mathrm{~m}$, corresponding to $10 \mathrm{~m}$ in the Estonian cores. This probably indicates substantial compaction of shales and mudstones in the stratotype section. An approximate supposed position of the Llandovery-Wenlock boundary and its depth in metres in the cores are also shown in Fig. 7. The ranges of the chitinozoan taxa more useful in the correlation with the boundary stratotype are listed below: Angochitina longicollis (in Viki 110.75-1780? m, Kaugatuma 229.10-269.10 m, Ohesaare 338.0-369.66 m, Ruhnu 451.0-487.70 m), Ramochitina nestorae (in Viki 134.80-134.90 m, Kaugatuma 233.05-245.50 m, Ohesaare 342.20-345.70 m, Ruhnu 455.30-457.48 m), Conochitina acuminata (in Viki 115.10-140.30 m, Kaugatuma $235.0-256.40 \mathrm{~m}$, Ohesaare $340.80-353.70 \mathrm{~m}$, Ruhnu $454.30-465.40 \mathrm{~m}$ ), C. cf. flamma (in Viki 114.30-140.30 m, Kaugatuma 231.05-258.70 m, Ohesaare 340.80-351.40 m, Ruhnu 454.05-459.70 m). Actually, even more significant are the disappearances of these species at the Llandovery-Wenlock boundary or close to it (Fig. 7). Among other species, appearing below the boundary and crossing it in the Hughley Brook section, Eisenackitina sp. 1 should be noted in the Viki (113.30-115.25 m), Kaugatuma (219.0-236.10 m), and Ohesaare (336.70-338.20 m) cores. In the stratotype section Ancyrochitina digitata and A. ansarviensis appear directly above the boundary. In the Estonian cores A. ansarviensis occurs mostly in the lowermost beds, and A. digitata near the boundary in the Viki (515.10-515.25 m) and Ruhnu (454.30-456.20 m) cores. Unfortunately, a new species Pterochitina hughleyensis sensu Mullins \& Aldridge, which appears just above the boundary at Hughley Brook (Fig. 6), was not found in Estonian cores. The first occurrence of Cingulochitina bouniensis was reported in the stratotype in sample $25 / 40,25.6 \mathrm{~cm}$ above the base of the Wenlock. The biozone of the same name was distinguished already in the Banwy River section, where it correlates with the uppermost part of the murchisoni graptolite Biozone (Mullins \& Loydell 2001). This species was found also in the Ruhnu core in the interval of 446.20-451.0 m. Earlier C. bouniensis was recognized in the Aizpute-41 core, at a level assigned also to the topmost part of the murchisoni Biozone (Loydell et al. 2003). Conochitina aff. tuba was present upward from sample 25/42. In Estonian cores this species has a similar position in the Viki (108.45$110.90 \mathrm{~m})$, Kaugatuma $(223.10-233.10 \mathrm{~m})$, and Ohesaare $(238.0-238.90 \mathrm{~m})$ cores. In Ruhnu this species was recognized lower, at the level of the supposed Llandovery-Wenlock boundary (454.05-467.10 m). Salopochitina bella, the index species of the succeeding biozone in Hughley Brook, has not been found in Estonian cores. 


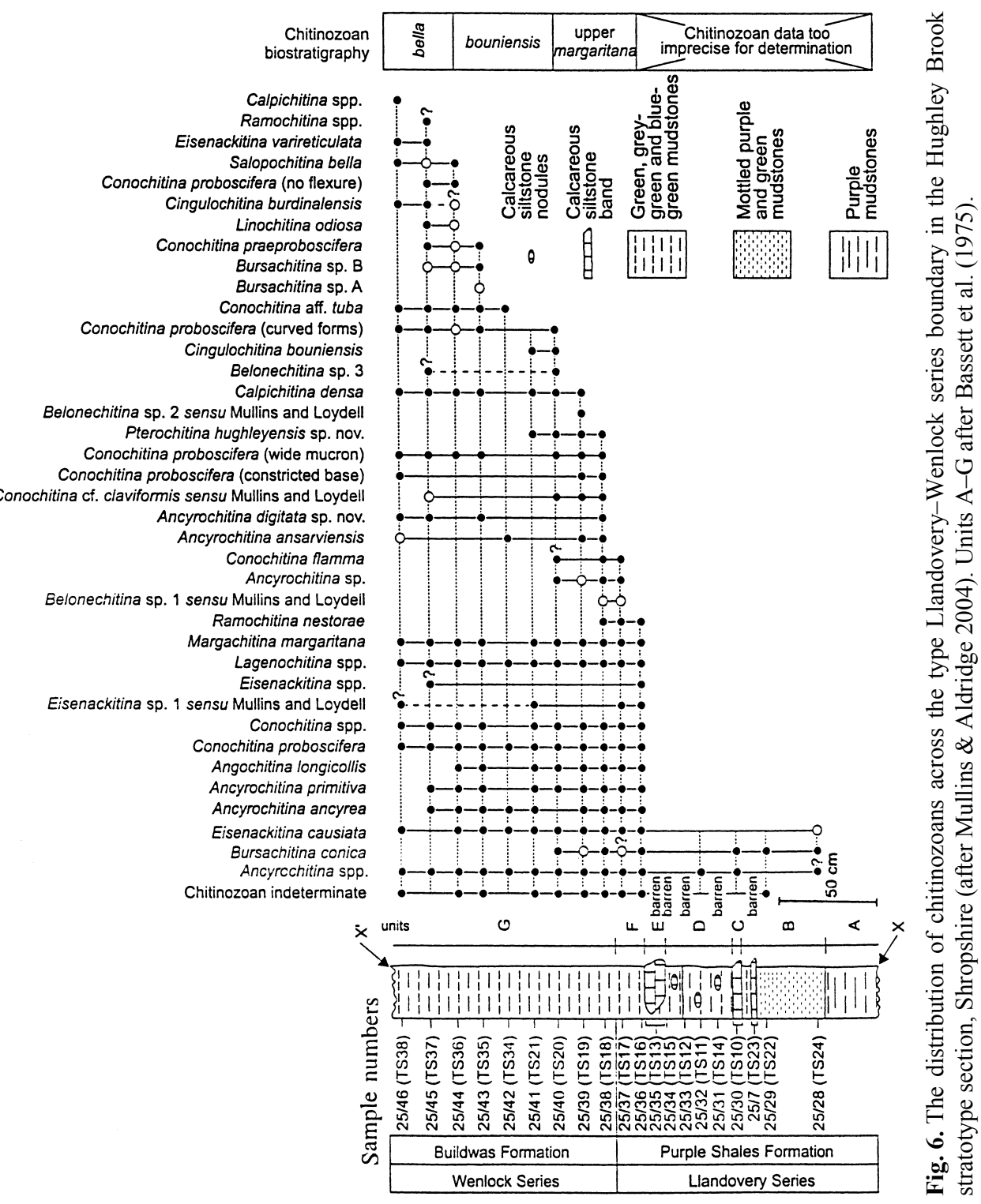




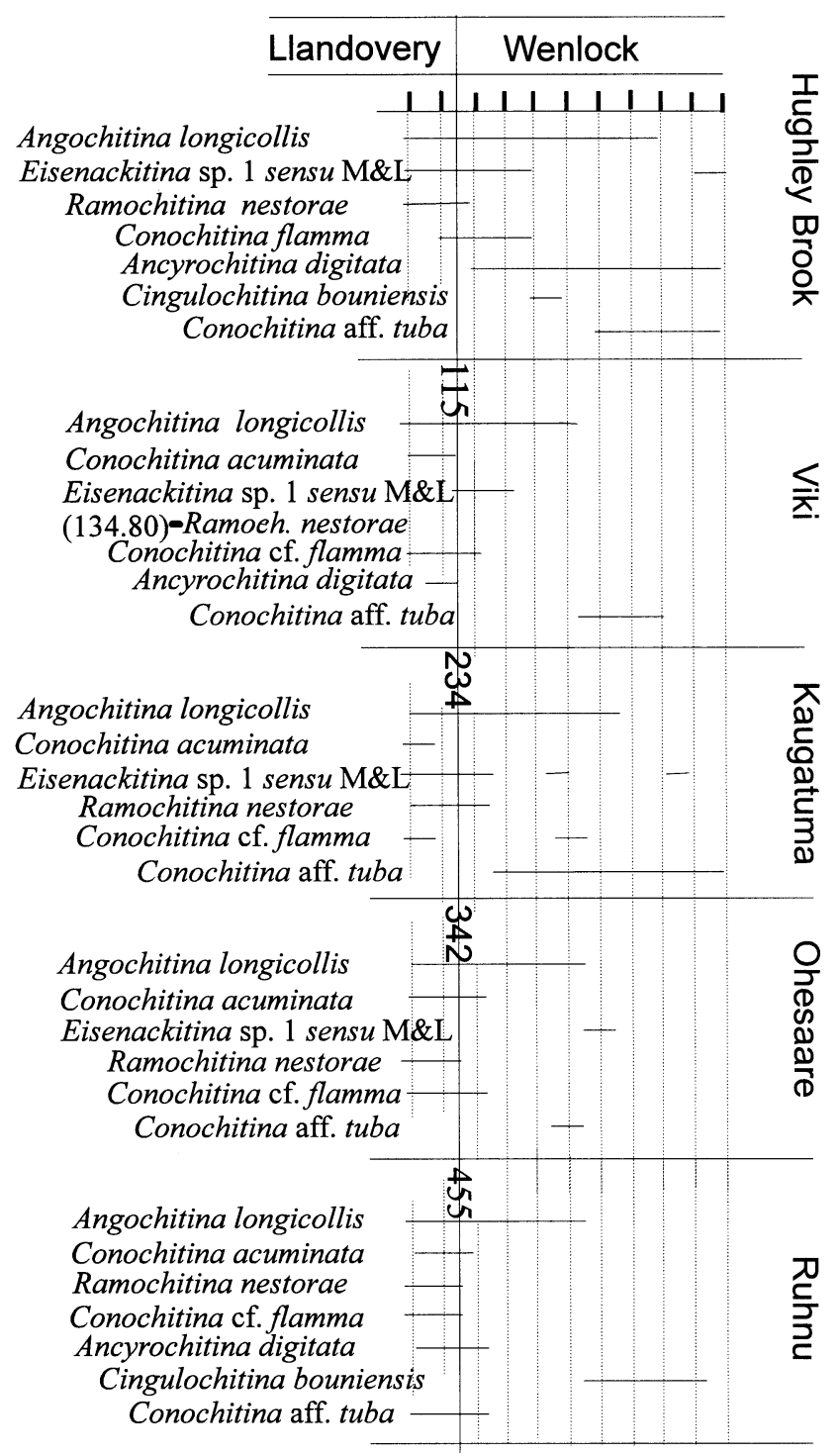

Fig. 7. The ranges of chitinozoan species stratigraphically most important in the correlation with the Llandovery-Wenlock boundary stratotype in Hughley Brook and the supposed position of the boundary in the studied West Estonian cores.

\section{DISCUSSION}

On the basis of published chitinozoan data Mullins \& Loydell (2001) and Mullins \& Aldridge (2004) present detailed reviews of correlation problems concerning the upper Llandovery and lower Wenlock strata around the world. 
Below, some remarks concerning disappearance levels of more common and stratigraphically more important species at the Llandovery-Wenlock boundary interval are added.

A. longicollis has been identified from the Telychian of different palaeocontinents (Verniers et al. 1995), but the upper limit of its range is disputable. It is correlated with the topmost Telychian in Bohemia (Dufka et al. 1995), Shropshire, England (Dorning 1981), and in the Yangtze Region, China (Geng et al. 1997). In Quebec, Canada, A. longicollis has been recovered from the centrifugus graptolite Zone (Asselin et al. 1989). Its disappearance has been related to the murchisoni Biozone in subsurface sections of Gotland (Grahn 1995), mainland of Sweden (Grahn 1998), Girvan area, Scotland (Vandenbroucke et al. 2003), RonquièresMonstreux area, Belgium (Verniers et al. 2002), Buttington Brick, Wales (Mullins \& Loydell 2002), Ventspils core (Nestor 1994) and Aizpute-41 core, West Latvia (Loydell et al. 2003), Ohesaare core (Nestor 1994) and Ruhnu core, West Estonia (Põldvere et al. 2003). In the Banwy River section (Mullins \& Loydell 2001), as well as in the Builth Wells district, Wales (Verniers 1999) and in the Mehaigne area, Belgium (Verniers 1982; Verniers et al. 2002), the disappearance of A. longicollis has been recorded at some level within the riccartonensis graptolite Zone.

Thus, the disappearance of $A$. longicollis is most often related to the murchisoni Biozone. Its earlier disappearance may be caused by gaps in sedimentation, insufficent data or unfavourable life conditions for this taxon. The reasons for the prolongation of its range remain unclear, but it is most likely that chitinozoan occurrences are not always precisely related to the graptolite zonation as graptolite data may be incomplete.

The disappearance level of C. acuminata has often been correlated with that of A. longicollis, for example, in Scotland (Vandenbroucke et al. 2002), Québec (Asselin et al. 1989), Builth Wells district (Verniers 1999), the Mehaigne area (Verniers 1982), Sweden (Grahn 1995, 1998), and China (Geng et al. 1997). In the Ireviken 3 section of Gotland (Nestor et al. 2002), C. acuminata disappears about $1 \mathrm{~m}$ above the Llandovery-Wenlock boundary determined by conodonts (Jeppsson \& Männik 1993). In the Banwy River section C. acuminata ranges up to the top of the Llandovery sequence and in the insectus Biozone. In the Estonian cores this species disappears just at the boundary or closely above it, being related to the middle part of the murchisoni Biozone (this study).

Ramochitina nestorae (= Gotlandochitina magnifica Nestor 1982) was identified by Y. Grahn from the spiralis Zone in the När core 1 and Rosendal core 1 in the subsurface of Gotland, ranging there up to the Llandovery-Wenlock boundary (Grahn 1995). The species was found also from the spiralis Zone in the Kallholn 1 core in the mainland of Sweden (Grahn 1998). Among all Estonian cores, $R$. nestorae has its longest range in the Kaugatuma core $(233.05-245.50 \mathrm{~m})$, but no graptolite datings are available from this core. Graptolites were not found from the Viki core either, but the single occurrence of $R$. nestorae in the sample from 134.80-134.90 m remains probably at a level below the LlandoveryWenlock boundary. A sparse occurrence of $R$. nestorae is caused very likely 
by environmental conditions, being related to relatively deep-water sediments (Nestor 1994). In all studied East Baltic sections where this species was found (Nestor 1994) it disappears around the Llandovery-Wenlock boundary interval. The presence of $R$. nestorae at the boundary in the Hughley Brook section (Mullins \& Aldridge 2004) makes it a good marker for identification of the LlandoveryWenlock boundary elsewhere, except in shallow-water and deepest-water graptolite sediments.

A bentonite layer is recognized in the Viki, Ohesaare, and Aizpute cores at depths of 115.0, 342.10, and $917.10 \mathrm{~m}$, respectively (Kiipli \& Kallaste 2002). This level is regarded by chitinozoans as the boundary between the Llandovery and Wenlock. It lies a couple of metres lower than the boundary established by conodonts (see Männik et al. 2002). In the Kaugatuma and Ruhnu cores a bentonite layer is recorded at depths of 236.90 and $458.90 \mathrm{~m}$, respectively, i.e. 3-4 m lower than the supposed Series boundary. It may be another bentonite layer, corresponding to that occurring in the Ohesaare core at a depth of $345.80 \mathrm{~m}$. The bentonite layer is considered as the lower boundary stratotype of the Jaani Regional Stage (see Nestor 1997).

In conclusion, the correlation of chitinozoan distribution in some West Estonian core sections and in the Llandovery-Wenlock boundary stratotype in the Hughley Brook section shows that the boundary corresponds to a level in the middle or in the upper part of the M. margaritana Biozone. In the Viki and Ohesaare cores the boundary coincides with a bentonite layer above the hitherto accepted boundary between the Adavere and Jaani regional stages, which correlates with a level in the middle of the murchisoni graptolite Biozone in the Ohesaare core.

\section{SYSTEMATIC PALAEONTOLOGY}

In this paper only the new species are described. The taxonomy follows the revised classification by Paris et al. (1999). The abbreviations used are: L, total length of the vesicle; ln, length of the neck; lapp, length of the appendices; $\mathrm{D}$, maximum vesicle diameter; dap, diameter of the aperture.

All figured chitinozoan specimens are deposited in collections Nos. 272 and 427 of the Institute of Geology at Tallinn University of Technology, Estonia.

Group CHITINOZOA Eisenack, 1931

Order PROSOMATIFERA Eisenack, 1972

Family CONOCHITINIDAE Eisenack, 1931 emend. Paris, 1981

Subfamily BELONECHITININAE Paris, 1981

Genus Belonechitina Jansonius, 1964 emend. Paris, Grahn, Nestor \& Lakova, 1999

Type species. Conochitina micracantha subsp. robusta Eisenack, 1959, pl. 3, fig. 4. 


\section{Belonechitina oeselensis sp. nov.}

Plate I, figures 5, 6

1994 Conochitina sp. 6 Nestor, p. 42, pl. 21, figs. 1, 2.

2003 Conochitina sp. 6 Nestor; Loydell et al., fig. 16-u.

Derivation of name. From Oesel, the old name of Saaremaa Island.

Holotype. GIT 427-3, Pl. I, figs. 5a, 5b, Kaugatuma core, depth 234.05-235.10 m, Velise Formation, Adavere Stage, Upper Llandovery.

Diagnosis. Vesicle conical, with concave or convex base and broadly to bluntly rounded basal margin. The vesicle flanks are slightly convex, tapering towards the aperture, where a thin-walled collerette occurs. The neck is not distinguished from the chamber, neither shoulder nor flexure is present. The central part of the base carries a wide conical mucron, formed by a thin membrane or wall. The vesicle wall has dense fine rugose or granular ornamentation, somewhat coarser at the base.

Dimensions. L, $180-250 \mu \mathrm{m} ; \mathrm{D}, 75-120 \mu \mathrm{m} ; \mathrm{L} / \mathrm{D}=2-2.5: 1$ (18 specimens in Fig. 8).

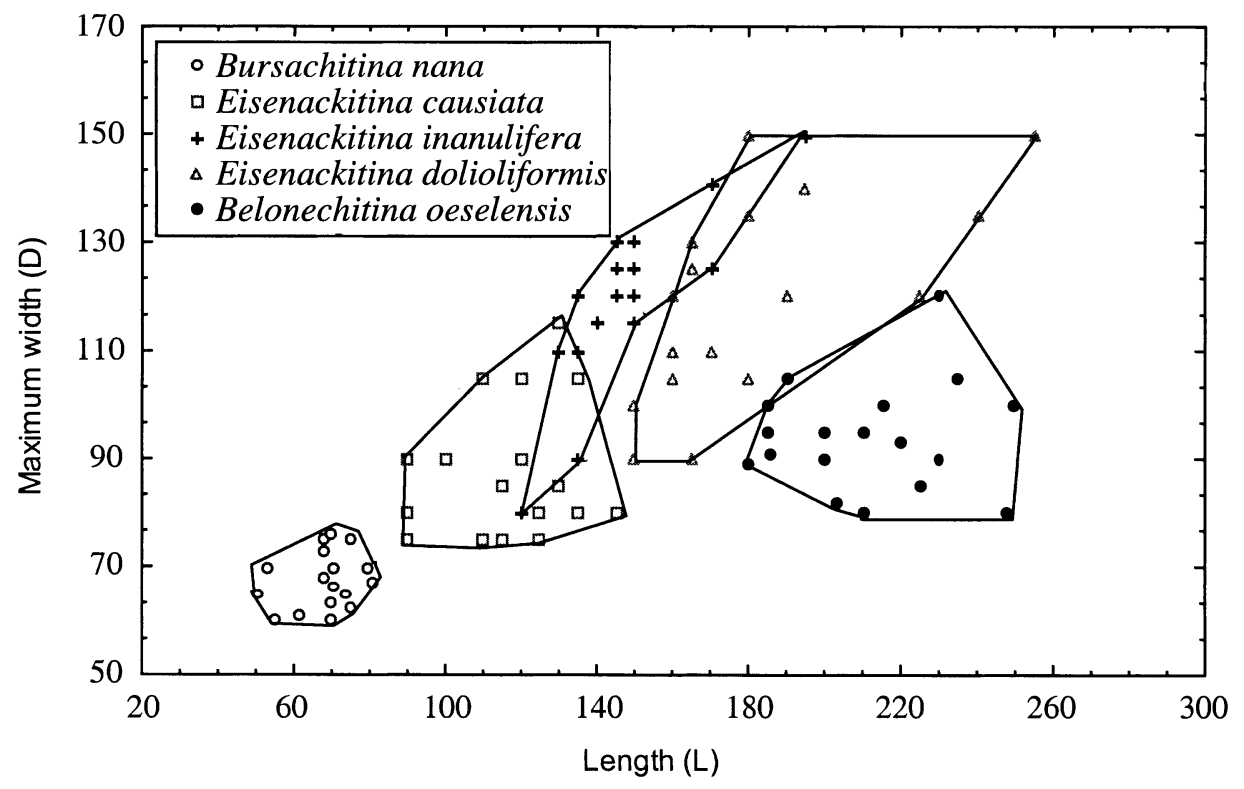

Fig. 8. Variation of the vesicle length (L) and maximum vesicle width (D) in $\mu \mathrm{m}$ in Bursachitina nana, Eisenackitina causiata, Eisenackitina inanulifera sp. nov., Eisenackitina dolioliformis, and Belonechitina oeselensis sp. nov. 
Remarks. Fine rugose or microgranular ornamentation is the most characteristic feature of $B$. oeselensis. The mucron is often hidden at the centre of the concave base (see Loydell et al. 2003, fig. 16-u) and not seen in the case of flattened vesicles. The maximum diameter is attained in the lower third of the vesicle. Conochitina visbyensis Laufeld has subcylindrical vesicle and is smaller: $\mathrm{L}=96$ $125 \mu \mathrm{m}, \mathrm{D}=38-52 \mu \mathrm{m}$ (see Laufeld 1974, p. 74, fig. 37). Bursachitina nestorae sensu Mullins \& Loydell (2001) is similar to B. oeselensis in the overall shape of the vesicle, but its wall is smooth and its mucron "arises from a hemisphaerical mound" on the base (p. 738). Belonechitina parvispinata Soufiane \& Achab (2000) has a vesicle covered with short (less than $4 \mu \mathrm{m}$ ), simple, lambda-shaped or multirooted spines.

Occurrence. Upper Llandovery: Velise and Jurmala formations of the Adavere Stage. Viki core, 144.40-172.0 m; Kaugatuma core, 240.05-270.10 m; Ohesaare core, $356.26 \mathrm{~m}$; Ruhnu core, 486.20-487.70 m; Nagli core, 612.0-642.0 m; Aizpute-41 core, 926.0-961.0 m; Ventspils core, 798.0?-842.80 m.

\section{Family LAGENOCHITINIDAE Eisenack, 1931, emend. Paris, 1981 Subfamily ANCYROCHITININAE Paris, 1981 \\ Genus Ancyrochitina Eisenack, 1955}

Type species. Conochitina ancyrea Eisenack, 1931 (holotype lost, neotype: Eisenack, 1955, pp. 163-164, pl. 2, fig. 7).

\section{Ancyrochitina mullinsi sp. nov. Plate II, figures 13, 14}

2001 Ancyrochitina gutnica Laufeld; Mullins \& Loydell, pl. 11, figs. 9, 10.

?2001 Ancyrochitina desmea Eisenack, 1964; Mullins \& Loydell, pl. 11, figs. 4-8.

Derivation of name. Named after the palynologist Gary Mullins.

Holotype. GIT 427-23, P1. II, figs. 13a, 13b, Kaugatuma core, depth 242.0242.10 m, Velise Formation, Adavere Stage, Upper Llandovery.

Diagnosis. Vesicle cylindro-conical with slightly developed flexure and shoulder. The base is flat or convex and broadly rounded basal edge carries 5-8 appendices, branching 4-5 times. The neck comprises about half the total length. The oral part of the neck bears very short simple or twice branching and vertically orientated spines. The middle part of the neck is sometimes provided with gently branching solitary spine(s). The aperture is smooth or finely fringed. Vesicle wall is smooth or finely granulated.

Dimensions. L, 110-180 $\mu \mathrm{m}$; lapp, 15-50 $\mu \mathrm{m}$; D, 60-85 $\mu \mathrm{m}$; L/ln = $1: 1$.

Remarks. Ancyrochitina mullinsi sp. nov. is similar to A. gutnica Laufeld, 1974, but appendices of the latter species have a long unbranched proximal part as well 
as long and well-developed curved spines in the aboral part of the neck, which decrease in size towards the aperture. Densely distributed tiny spines of A. mullinsi in the oral part of the neck are lacking in A. gutnica. Ancyrochitina desmea Eisenack, 1964 has strongly branching thick appendices at the basal edge, $156 \mu \mathrm{m}$ in length, and in the middle part of the neck, $105 \mu \mathrm{m}$ in length (Eisenack 1964, pp. 325, pl. 29, figs. 1-3). Ancyrochitina ramosaspina Nestor, 1994 has straight and rigid appendices but lacks tiny spines in the oral part of the neck.

Occurrence. Upper Llandovery: the uppermost part of the Velise Formation of the Adavere Stage. Kaugatuma core, 240.0-255.1 m; Viki core, 125.0-134.0 m; Ruhnu core, 456.15-463.20 m. In the Banwy River section in Wales A. mullinsi occurs in the spiralis, lapworthi, and insectus graptolite zones of the uppermost Llandovery.

\author{
Order OPERCULATIFERA Eisenack, 1972 \\ Family DESMOCHITINIDAE Eisenack, 1931, emend Paris, 1981 \\ Subfamily EISENACKITININAE Paris, 1981 \\ Genus Eisenackitina Jansonius, 1964
}

Type species. Eisenackitina castor Jansonius, 1964

Eisenackitina inanulifera sp. nov.

Plate I, figures $10-12$

?1982 Eisenackitina sp. A, Verniers 1982, pl. 5, fig. 92.

?2001 Eisenackitina aff. anulifera Verniers; Mullins \& Loydell, pl. 3, figs. 5, 6.

Derivation of name. Refers to the lack of the ring-like thickenings of the vesicle wall as well as to similarity of the vesicle shape of the new species to E. anulifera Verniers, 1999.

Holotype. GIT 427-9, P1. I, fig. 11, Kaugatuma core, 242.0-242.10 m, Velise Formation, Adavere Stage, Upper Llandovery, Saaremaa Island, Estonia.

Diagnosis. Vesicle (cylindro-)conical or (cylindro-)ovoid, with slightly convex flanks and broadly rounded basal edge. The flexure and shoulders are more or less developed. The neck is short or missing. The base is slightly convex or flat with a little button-like mucron in the centre. The vesicle wall is felt-like, rugose or finely granulated. The ornamentation is best developed at the shoulders and at the aboral part of the body.

Dimensions. L, 120-190 $\mu \mathrm{m}$; D, $80-150 \mu \mathrm{m}$; dap., 50-75 $\mu \mathrm{m}$ (16 specimens in Fig. 8).

Remarks. In overall shape E. inanulifera is quite similar to E. anulifera Verniers, 1999, but lacks the ring-like thickenings on the chamber and base as well 
as circular-membrane type of mucron (or impression) of the latter species. E. inanulifera is similar to E. aff. anulifera sensu Mullins \& Loydell 2001 in having a circular scar, but it usually has also ring-like thickenings and its aperture is somewhat narrower $(36.3-50.0 \mu \mathrm{m})$. E. dolioliformis Umnova, 1976 has a wide short mucron and is larger $(141.0-255.0 \mu \mathrm{m})$. E. causiata Verniers, 1999 is smaller and has neither neck nor shoulders.

Occurrence. Upper Llandovery and Lower Wenlock: Velise Formation of the Adavere Stage and Riga and Jaani formations of the Jaani Stage. Ohesaare core, 338.0-358.70 m; Viki core, 114.40-158.50 m; Kaugatuma core, 214.0-269.10 m; Ruhnu core, $454.60-465.40 \mathrm{~m}$.

\section{ACKNOWLEDGEMENTS}

This study was supported by the Estonian Science Foundation (grants Nos. 5088 and 5920). I am grateful to referees D. Kaljo and J. Verniers for their useful comments, V. Mikli for SEM photographs, and G. Baranov for help with composing the plates.

\section{REFERENCES}

Asselin, E., Achab, A. \& Bourque, P. A. 1989. Chitinozoaires du Silurien inferieur dans la région de la baie des Chaleurs en Gaspésie, Québec, Canada. Can. J. Earth Sci., 26, 2435-2449.

Bassett, M. G., Holland, C. H., Rickards, R. B. \& Warren, P. T. 1975. The type Wenlock Series. Rep. Inst. Geol. Sci., 75, 1-19.

Dorning, K. J. 1981. Silurian Chitinozoa from the type Wenlock and Ludlow of Shropshire, England. Rev. Palaeobot. Palynol., 34, 205-208.

Dufka, P., Křiž, J. \& Štorch, P. 1995. Silurian graptolites and chitinozoans from the Uranium Industry boreholes drilled in 1968-1971 (Prague Basin, Bohemia). Bull. Czech Geol. Surv., 70, 5-14.

Eisenack, A. 1964. Mikrofossilien aus dem Silur Gotlands. Chitinozoen. Neues Jb. Geol. Paläont. Abh., 120, 308-342.

Geng Liang-Yu, Qian Zhe-Shu, Ding Lian-Shen, Wang Yue, Wang Gen-Xian \& Cai Xi-Yao. 1997. Silurian chitinozoans from the Yangtze Region. Palaeoworld, 8, 1-152.

Grahn, Y. 1995. Silurian Chitinozoa and biostratigraphy of subsurface Gotland. GFF, 117, 57-65.

Grahn, Y. 1998. Lower Silurian (Llandovery-Middle Wenlock) biostratigraphy of the mainland of Sweden. GFF, 120, 273-283.

Jeppsson, L. \& Männik, P. 1993. High resolution correlations between Gotland and Estonia near the base of the Wenlock. Terra Nova, 5, 348-358.

Kaljo, D. 1962. On the boundary of the Llandoverian and Wenlockian in the East Baltic. ENSV Tead. Akad. Geol. Inst. Uurimused, 10, 97-113.

Kiipli, T. \& Kallaste, T. 2002. Correlation of Telychian sections from shallow to deep sea facies in Estonia and Latvia based on sanidine composition of bentonites. Proc. Estonian Acad. Sci. Geol., 51, 143-156.

Laufeld, S. 1974. Silurian Chitinozoa from Gotland. Fossils and Strata, 5, 1-130.

Loydell, D. K. \& Nestor, V. Integrated graptolite and chitinozoan biogeography of the upper Telychian (Llandovery, Silurian) of the Ventspils D-3 core, Latvia. Geol. Mag. (in press). 
Loydell, D. K., Kaljo, D. \& Männik, P. 1998. Integrated biostratigraphy of the lower Silurian of the Ohesaare core, Saaremaa, Estonia. Geol. Mag., 135, 769-783.

Loydell, D. K., Männik, P. \& Nestor, V. 2003. Integrated biostratigraphy of the lower Silurian of the Aizpute-41 core, Latvia. Geol. Mag., 140, 205-229.

Mabillard, J. E. \& Aldridge, R. J. 1985. Microfossil distribution across the base of the Wenlock Series in the type area. Palaeontology, 28, 89-100.

Männik, P., Kallaste, T. \& Martma, T. 2002. Dating of the Ireviken Event and the problem of the Llandovery-Wenlock boundary, some possible developments. In The Fifth Baltic Stratigraphical Conference "Basin Stratigraphy - Modern Methods and Problems", Sep 22-27, 2002, Vilnius, Lithuania: Extended Abstracts, pp. 114-116. Vilnius.

Mullins, G. L. 2000. A chitinozoan morphological lineage and its importance in Lower Silurian stratigraphy. Palaeontology, 43, 359-373.

Mullins, G. L. \& Aldridge, R. J. 2004. Chitinozoan biostratigraphy of the basal Wenlock Series (Silurian) global stratotype section and point. Palaeontology, 47, 745-773.

Mullins, G. L. \& Loydell, D. K. 2001. Integrated Silurian chitinozoan and graptolite biostratigraphy of the Banwy River section, Wales. Palaeontology, 44, 731-781.

Mullins, G. L. \& Loydell, D. K. 2002. Integrated lower Silurian chitinozoan and graptolite biostratigraphy of Buttington Brick Pit, Wales. Geol. Mag., 139, 89-96.

Nestor, H. 1997. Silurian. In Geology and Mineral Resources of Estonia (Raukas, A. \& Teedumäe, A., eds.), pp. 89-106. Estonian Academy Publishers, Tallinn.

Nestor, H. \& Nestor, V. 2002. Upper Llandovery to middle Wenlock (Silurian) lithostratigraphy and chitinozoan biostratigraphy in southwestern Estonia and northernmost Latvia. Proc. Estonian Acad. Sci. Geol., 51, 67-87.

Nestor, V. 1984. Zonal distribution of chitinozoans in the Wenlockian Jaani Stage of Estonia and the problem of its upper boundary. In Stratigraphy and Early Paleozoic Sediments of East Baltic (Männil, R. \& Mens, K., eds.), pp. 119-127. Institute of Geology, Academy of Sciences of ESSR, Tallinn (in Russian).

Nestor, V. 1990. Silurian chitinozoans. In Field Meeting, Estonia. An Excursion Guidebook (Kaljo, D. \& Nestor, H., eds.), pp. 80-83. Tallinn.

Nestor, V. 1994. Early Silurian Chitinozoans of Estonia and North Latvia. Academia, Vol. 4.

Nestor, V., Einasto, R. \& Loydell, D. K. 2002. Chitinozoan biostratigraphy and lithological characteristics of the Lower and Upper Visby boundary Beds in the Ireviken 3 section, Northwest Gotland. Proc. Estonian Acad. Sci. Geol., 51, 215-226.

Paris, F., Grahn, Y., Nestor, V. \& Lakova, I. 1999. A revised chitinozoan classification. J. Paleont., 73, 549-570.

Põldvere, A. (ed.). 2003. Ruhnu (500) drill core. Estonian Geol. Sections, 5.

Soufiane, A. \& Achab, A. 2000. Upper Ordovician and Lower Silurian chitinozoans from central Nevada and Arctic Canada. Rev. Palaeobot. Palynol., 113, 165-187.

Vandenbroucke, T., Verniers, J. \& Clarkson, E. N. K. 2003. A chitinozoan biostratigraphy of the Upper Ordovician and lower Silurian strata of the Girvan area, Midland Valley, Scotland. Trans. Roy. Soc. Edinburgh: Earth Sci., 93, 111-134.

Verniers, J. 1982. The Silurian Chitinozoa of the Mehaigne Area (Brabant Massif, Belgium). Prof. Pap. Geol. Surv. Belgium, 192, 1-76.

Verniers, J. 1999. Calibration of Chitinozoa versus graptolite biozonation in the Wenlock of Builth Wells district (Wales, U.K.), compared with other areas in Avalonia and Baltica. Boll. Soc. Paleontol. Italiana, 38, 359-380.

Verniers, J., Nestor, V., Paris, F., Dufka, P., Sutherland, S. \& Van Grootel, G. 1995. A global Chitinozoa biozonation for the Silurian. Geol. Mag., 132, 651-666.

Verniers, J., Van Grootel, G., Louwye, S. \& Diependaele, B. 2002. The chitinozoan biostratigraphy of the Silurian of the Ronquiéres-Monstreux area (Brabant Massif, Belgium). Rev. Palaeobot. Palynol., 118, 287-322. 


\title{
Margachitina margaritana biotsooni kitiinikud ja Llandovery-Wenlocki piir Lääne-Eesti läbilõigetes
}

\begin{abstract}
Viiu Nestor
On esitatud andmed kitiinikute leviku kohta Ülem-Llandovery ja AlamWenlocki piirialal Viki, Kaugatuma, Ohesaare ning Ruhnu puursüdamikes, mille põhjal on neid läbilõikeid korreleeritud rahvusvahelise Llandovery-Wenlocki piiristratotüübiga Hughley Brookis Inglismaal. On selgitatud stratigraafiliselt olulisemad taksonid selle piiri määramiseks Lääne-Eesti läbilõigetes. Ohesaare ja Viki puursüdamikes langeb piir kokku bentoniidikihtidega, mis asuvad kõrgemal Adavere ja Jaani lademete ametlikust piirist, vastates ligikaudu murchisoni graptoliidi tsooni keskosale Ohesaare puuraugu andmetel. Töös on kirjeldatud kolme uut liiki.
\end{abstract}

